\title{
PENGEMBANGAN INSTRUMEN PENILAIAN KOMPETENSI MEMBACA PADA MATA PELAJARAN BAHASA INDONESIA KELAS VII BERBASIS QUIPPER SCHOOL
}

\author{
Ana Puji Astuti \\ SMP Muhammadiyah 8 BATU \\ Email : apaastuti71@gmail.com
}

\begin{abstract}
ABSTRAK
Penelitian pengembangan ini bertujuan menghasilkan sebuah produk yang berupa instrumen penilaian kompetensi membaca pelajaran Bahasa Indonesia kelas VII berbasis Quipper School. Penelitian ini difokuskan pada aspek struktur, isi, dan bahasa yang menggunakan Quipper School sebagai media online dengan teknik tes objektif. Pengembangan produk yang berupa instrumen menggunakan model R2D2 (recursive, reflective, design, and development). Metode penelitian pengembangan juga didasarkan pada pendapat Sugiyono (2013:407) bahwa metode penelitian digunakan untuk menghasilkan produk tertentu dan menguji keefektifan produk tersebut. Instrumen penilaian yang digunakan memiliki tiga fokus kerja, yaitu (1) penetapan, (2) desain dan pengembangan, dan (3) diseminasi. Produk yang dikembangkan adalah instrumen penilaian kompetensi membaca kelas VII berbasis Quipper School dengan hasil telaah berupa (1) penilaian, (2) masukan kritik dan saran dengan fokus pembahasan pada tiga aspek, yaitu struktur, isi, dan bahasa.yang melibatkan tim ahli dan praktisi. Produk pengembangan ini memiliki struktur (1) soal semester gasal dan (2) soal semester genap. Kajian terhadap produk hasil penelitian pengembangan ini difokuskan terhadap keunggulan produk, kelemahan produk, dan antisipasi kelemahan produk. Produk yang dikembangkan melalui penelitian tesis ini adalah instrumen penilaian standar kompetensi membaca kelas VII berbasis Quipper School. Karena berbasis Quipper School, ada dua aspek yang ditelaah oleh ahli, yaitu (1) struktur dan isi dan (2) bahasa. Produk yang dikembangkan adalah instrumen penilaian untuk standar kompetensi membaca pada mata pelajaran Bahasa Indonesia kelas VII yang terdiri atas (1) soal semester gasal ada 4 Kompetensi Dasar dan (2) soal semester genap ada 5 Kompetensi Dasar. Bahasa yang digunakan dalam produk ini adalah bahasa Indonesia dengan ragam bahasa formal yang penulisannya disesuaikan tata aturan EYD (Ejaan Yang Disempurnakan).
\end{abstract}

Kata kunci: Pengembangan Instrumen Penilaian, Kompetensi Membaca, Quipper School.

\begin{abstract}
This research and development is aimed to produce a product in the form of reading competency assessment instruments on Bahasa Indonesia lessons on Quipper School grade VII. This study is focused on aspects of the structure, content, and language by using Quipper School as an online media with the objective for testing techniques. The product development is in the form of the instrument using the model R2D2 (recursive, reflective, design, and development). The research method development is also based on the statement from Sugiyono (2013: 407) that the research methods used to produce a specific product and test the effectiveness of the product. The instrument for assessment is focused on three works, namely: (1) the determination, (2) design and development, and (3) dissemination. The developed products are reading competency assessment instrument based Quipper School seventh grade with the review in the form of: (1) assessment, (2) input criticism and suggestions with the discussion focusing on three aspects, namely the
\end{abstract}


structure, content, and language, involving a team of experts and practitioners. The structures of the product development are: (1) test on odd semester and (2) test on second semester. The study on product development research is focused on product excellence, product weaknesses, and the anticipated weakness of the product. The developed products through this research is the assessment instrument grade reading competency standardsbased Quipper School grade VII. As the research is based on Quipper School, there are two aspects that are reviewed by experts, namely: (1) the structure and content, and (2) language. The developed products is a standard assessment instrument for the reading competency in the subjects of Bahasa Indonesia grade VII consisting of (1) test on odd semester with four basic competencies and (2) test on second semester with 5 basic competencies. The language used in this product is Bahasa Indonesia with a variety of formal languages customized with writing rules governing the EYD (Standarised Spelling).

Key words: Development of Assessment Tools, Competency Reading, Quipper School.

\section{PENDAHULUAN}

Membaca adalah proses aktif pikiran melalui mata untuk menangkap pesan atau makna dalam bacaan. Sahab (2012:31) menyatakan bahwa membaca adalah proses rekognisi, interpretasi, dan persepsi terhadap bahan-bahan yang tertulis atau tercetak. Dalam kegiatan membaca pembaca otomatis merekognisi simbolsimbol bahasa, kemudian menginterpretasi makna dari setiap simbol itu dan memahami pesan yang disampaikan oleh penulis. Dengan membaca, selain menangkap pesan atau informasi, sebenarnya pembaca juga akan mempertajam keterampilan mekanis dan memperluas pengetahuan bahasanya. Oleh sebab itu, dalam kegiatan membaca terdapat dua proses yang otomatis dilaksanakan oleh pembaca, yaitu proses mekanis dan proses pemahaman (Tarigan, 2012:11). Beredarnya media komunikasi massa dengan teknologi yang canggih menuntut seseorang untuk menguasai keterampilan membaca. Terlebih bagi mereka yang memutuskan untuk melanjutkan sekolah ke jenjang perguruan tinggi, membaca akan menjadi hal wajib yang harus sering dilakukan. Dengan demikian, keterampilan membaca itu harus dikuasai dengan baik karena akan sangat berguna dalam kehidupan sehari-hari.
Karena pentingnya keterampilan membaca untuk dikuasai, Kurikulum 2006 menempatkan keterampilan membaca sebagai salah satu standar kompetensi dalam mata pelajaran Bahasa Indonesia yang wajib diajarkan pada seluruh peserta didik mulai jenjang SD sampai SMA. Hal itu tertuang dalam Permendiknas RI No. 22 Tahun 2006 tentang Standar Isi. Dalam permendiknas tersebut ditetapkan bahwa ruang lingkup mata pelajaran Bahasa Indonesia pada jenjang SD, SMP, dan SMA mencakup komponen kemampuan berbahasa dan bersastra yang meliputi aspek (1) mendengarkan, (2) berbicara, (3) membaca, dan (4) menulis.

Penetapan keterampilan membaca sebagai kompetensi yang diajarkan di sekolah berimplikasi pada pengembangan instrumen penilaiannya. Guru Bahasa Indonesia perlu mengembangkan instrumen penilaian yang sesuai untuk menilai pencapaian hasil belajar siswa pada aspek membaca. Permendiknas RI No. 20 Tahun 2007 tentang Standar Penilaian Pendidikan menetapkan bahwa instrumen penilaian, baik yang digunakan oleh pendidik, sekolah, maupun pemerintah, harus memenuhi persyaratan substansi, konstruksi, dan bahasa. Pada aspek 
substansi, instrumen penilaian harus merepresentasikan kompetensi yang dinilai. Pada aspek konstruksi, instrumen penilaian harus memiliki bentuk dan teknik yang sesuai. Pada aspek bahasa, instrumen harus menggunakan bahasa yang baik dan benar serta komunikatif sesuai dengan taraf perkembangan siswa. Oleh sebab itu, pengembangan instrumen penilaian kompetensi membaca itu penting dilakukan.

Dalam penyelenggaraan pendidikan di sekolah, penilaian merupakan salah satu langkah penting yang harus dilakukan oleh setiap guru. Diterangkan oleh Haryati (2009:13) bahwa penilaian itu bisa dimanfaatkan untuk memantau proses kemajuan dan perkembangan hasil belajar peserta didik sesuai potensi mereka, juga sekaligus sebagai umpan balik kepada guru agar dapat menyempurnakan perencanaan pembelajaran. Dengan mengetahui hasil belajar peserta didik, guru bisa memutuskan apakah seorang siswa perlu mendapatkan remidi atau tidak serta mengetahui pada aspek-aspek apa saja siswa tersebut memiliki kekurangan. Dengan mengetahui hasil belajar peserta didik, guru juga bisa introspeksi diri serta mengevaluasi instrumen yang ia gunakan, strategi yang diterapkan dalam kelas, atau hal-hal lain terkait dengan pembelajaran.

Lebih dari itu, penilaian dilaksanakan bisa untuk berbagai macam tujuan. Arifin (2013:15) menyebutkan secara lengkap tujuan penilaian, meliputi (1) untuk mengetahui tingkat penguasaan peserta didik terhadap materi yang telah diberikan; (2) untuk mengetahui kecakapan, motivasi, bakat, minat, dan sikap peserta didik terhadap program pembelajaran; (3) untuk mengetahui tingkat kemajuan dan kesesuaian hasil belajar peserta didik dengan standar kompetensi dan kompetensi dasar yang telah ditetapkan; (4) untuk mendiagnosis keunggulan dan kelemahan peserta didik dalam mengikuti kegiatan pembelajaran; (5) untuk seleksi, yaitu memilih dan menentukan peserta didik yang sesuai dengan jenis pendidikan tertentu; (6) untuk menempatkan peserta didik sesuai potensi yang dimilikinya; dan (7) untuk menentukan kenaikan kelas.

Guru Bahasa Indonesia di SMP Muhammadiyah 8 Batu pada setiap tahunnya sudah membuat instrumen penilaian, namun belum pernah dilaksanakan uji validitas, analisis, dan evaluasi. Analisis memang sudah dilaksanakan, namun hanya di akhir semester. Itu pun sebatas analisis hasil belajar siswa, bukan analisis yang secara khusus bertujuan untuk mengembangkan instrumen penilaian. Secara konseptual, penilaian yang dilaksanakan di SMP Muhammadiyah 8 Batu masih belum memperhatikan konsep-konsep dan prinsip-prinsip penilaian yang ideal. Analisis dilakukan sebatas hanya untuk kepentingan administratif. Hal tersebut menjadi alasan peneliti untuk mengembangkan instrumen penilaian kompetensi membaca mata pelajaran Bahasa Indonesia SMP/MTs Kurikulum 2006 berbasis online.

Saat ini penilaian yang diselenggarakan di SMP Muhammadiyah 8 Batu masih konvensional, yakni masih menggunakan kertas, belum memanfaatkan teknologi internet. Menurut peneliti, sudah saatnya siswa diberi pengalaman baru dengan mengikuti penilaian secara online. Hal ini akan memberikan pengalaman penilaian yang baru sehingga siswa akan lebih mengenal teknologi. Dengan memanfaatkan teknologi semacam itu, koreksi tidak akan memakan waktu lama karena dilaksanakan oleh sistem aplikasi. Tentu hal ini lebih 
praktis dan efisien. Guru selama ini sudah memiliki beban tugas yang sangat banyak. Dengan hadirnya instrumen penilaian berbasis online, beban guru akan sedikit berkurang. Dengan sistem online, penilaian bisa dilaksanakan serentak dalam batas waktu tertentu dan hasilnya pun bisa langsung diketahui saat itu juga. Oleh sebab itu, menarik kiranya bila peneliti menghadirkan instrumen penilaian berbasis online. Apalagi tahun 2015 ini pemerintah mengadakan UN (Ujian Nasional) untuk siswa SMA dan MA secara online khusus pada beberapa sekolah yang ditunjuk. Hal itu berimplikasi pada pengumuman hasil Ujian Nasional yang juga bisa dilaksanakan secara online meski saat ini masih terbatas pada beberapa sekolah yang ditunjuk. Dengan demikian, sistem online adalah sistem yang layak untuk dikembangkan dalam sebuah penilaian karena memiliki dampak positif dari segi sosial.

Peneliti menemukan tiga penelitian pengembangan yang serupa dengan penelitian ini. Pertama, penelitian Nurgiyantoro (2008) berjudul Pengembangan Model Authentic Assessment dalam Pembelajaran Bahasa. Tujuan pada penelitian tersebut adalah menghasilkan model penilaian otentik dalam pembelajaran bahasa, namun model tersebut belum bersifat praktis karena pengguna dan medianya belum ditentukan secara spesifik. Kedua, penelitian Rahayu (2008) yang berjudul Pengembangan Instrumen Penilaian dalam Pendidikan Matematika Realistik Indonesia (PMRI) di SMPN 17 Palembang. Penelitian tersebut memang sama-sama bertujuan menghasilkan instrumen penilaian, namun pada mata pelajaran Matematika. Ketiga, penelitian Khoiri (2014) berjudul Pengembangan Perangkat Penilaian Pembelajaran Menulis Karya Ilmiah
(Bahasa Indonesia) untuk Siswa SMP. Penelitian tersebut memang sama-sama bertujuan mengembangkan alat penilaian, namun lebih fokus pada sebuah kompetensi dasar saja, yakni menulis karya ilmiah. Oleh sebab itu, pengembangan instrumen penilaian kompetensi membaca mata pelajaran Bahasa Indonesia SMP/MTs Kurikulum 2006 berbasis online ini dinilai layak untuk dilaksanakan.

Untuk menciptakan instrumen penilaian yang berbasis online, digunakan Quipper School, sebuah situs yang dirancang khusus untuk pembelajaran dan penilaian yang berbasis online. Keputusan ini didasarkan pada pertimbangan waktu, tenaga, dan biaya. Dibanding dengan pembuatan situs yang memakan waktu relatif lama, tenaga yang relatif besar, dan biaya yang juga relatif banyak, Quipper School secara resmi menyatakan sebagai media pembelajaran berbasis online yang disediakan secara gratis bagi para guru dan siswa. Bahkan, lebih dari itu, Quipper School juga menyediakan materimateri dan soal-soal yang juga bisa dipakai oleh guru untuk menyelenggarakan pembelajaran dan penilaian secara gratis. Dengan Quipper School guru bisa mempersiapkan soal ujian atau ulangan dengan cepat. Dengan menggunakan Quipper School juga, pengembangan instrumen penilaian secara online bisa dilaksanakan dalam waktu yang relatif cepat, serta dengan biaya dan tenaga yang relatif kecil. Berbeda dengan penelitianpenelitian sejenis yang membahas tentang pengembangan instrumen penilaian khususnya dengan menggunakan media online, Webside Elerning "Quipper School" belum ada sebelumnya. Oleh sebab itu, peneliti tertarik untuk mengembangkan instrumen penilaian kompetensi membaca mata pelajaran 
Bahasa Indonesia SMP/MTs Kurikulum 2006 yang berbasis Quipper School tersebut.

Adapun tujuan penelitian pengembangan ini menghasilkan sebuah produk yang berupa instrumen penilaian standar kompetensi membaca pelajaran Bahasa Indonesia kelas VII berbasis Quipper School

\section{METODE}

Proses pengembangan produk ini menggunakan prinsip kerja R2D2 (recursive, reflective design and development). Instrumen penilaian kompetensi membaca pada siswa kelas VII berbasis Quipper School ini memiliki tiga fokus kerja, yaitu (1) penetapan, (2) desain dan pengembangan, dan (3) diseminasi. Dalam tiap-tiap fokus tersebut terdapat rincian kegiatan yang harus dilaksanakan oleh peneliti secara rekursif, nonlinier, reflektif, dan partisipatif. Sugiyono (2013:407) memperkuat bahwa metode penelitian dan pengembangan itu digunakan untuk menghasilkan produk tertentu dan menguji keefektifan produk tersebut. Selain itu, Sujadi (2003:164) menjelaskan bahwa penelitian dan pengembangan atau research and development adalah suatu proses atau langkah-langkah untuk mengembangkan produk baru atau menyempurnakan produk yang telah ada dengan cara yang dapat dipertanggungjawabkan. Secara garis besar Willis (2009:314) mengemukakan tiga prinsip dasar R2D2, yaitu recursion, reflection, dan participation. Uji coba produk yang dilaksanakan ada lima yaitu (1) desain uji coba; (2) subjek data; (3) jenis data; (4) instrumen pengumpulan data; dan (5) teknik analisis data.
Prinsip recursion (rekursif) adalah prinsip yang mengharuskan peneliti membuat keputusan-keputusan sementara sehingga keputusan-keputusan itu bisa direfleksi, ditinjau kembali, dan direvisi secara berulang dan nonlinier (tidak berurutan) meski proses pengembangan belum selesai. Prinsip recursion (rekursif) adalah prinsip yang mengharuskan peneliti membuat keputusan-keputusan sementara sehingga keputusan-keputusan itu bisa direfleksi, ditinjau kembali, dan direvisi secara berulang dan nonlinier (tidak berurutan) meski proses pengembangan belum selesai. Jadi, nonlinier itu bukan prinsip yang berdiri sendiri, melainkan sebuah konsekuensi logis karena adanya prinsip rekursif. Dalam prinsip ini peneliti diperkenankan bekerja secara simultan dan tidak harus mengikuti urut-urutan pertahapan.

Prinsip reflection (refleksif) adalah prinsip yang mengharuskan peneliti melakukan refleksi, memikirkan ulang secara sungguh-sungguh, mencari dan menemukan umpan balik, serta mencari dan menemukan ide-ide dari berbagai sumber selama proses pengembangan. Prinsip participatory (partisipatif) adalah prinsip yang mengharuskan peneliti mengajak orang lain berpartisipasi dalam penelitian. Partisipasi itu boleh diminta untuk seluruh proses penelitian, boleh juga untuk sebagian saja. Partisipan boleh membantu peneliti melaksanakan refleksi, atau sebatas menjadi subjek uji coba (tryout).

Dalam pengembangan instrumen penilaian kompetensi membaca pada siswa kelas VII berbasis Quipper School ini diperlukan tiga ahli, yaitu (1) ahli di bidang mata pelajaran Bahasa Indonesia, (2) ahli di bidang Website Elerning/ 
praktisi Quipper School, dan (3) ahli di bidang penilaian. Oleh sebab itu, diperlukan prinsip partisipatif dalam penelitian dan pengembangan ini. Dengan demikian, dapat ditegaskan bahwa penelitian dan pengembangan instrumen penilaian kompetensi membaca pada siswa kelas VII berbasis Quipper School ini dilaksanakan secara rekursif, reflektif, nonlinier, dan partisipatif.

Tabel 1: Langkah-Langkah Kerja Penelitian dan Pengembangan Instrumen Penilaian Standar Kompetensi Membaca Kelas VII Berbasis Quipper School

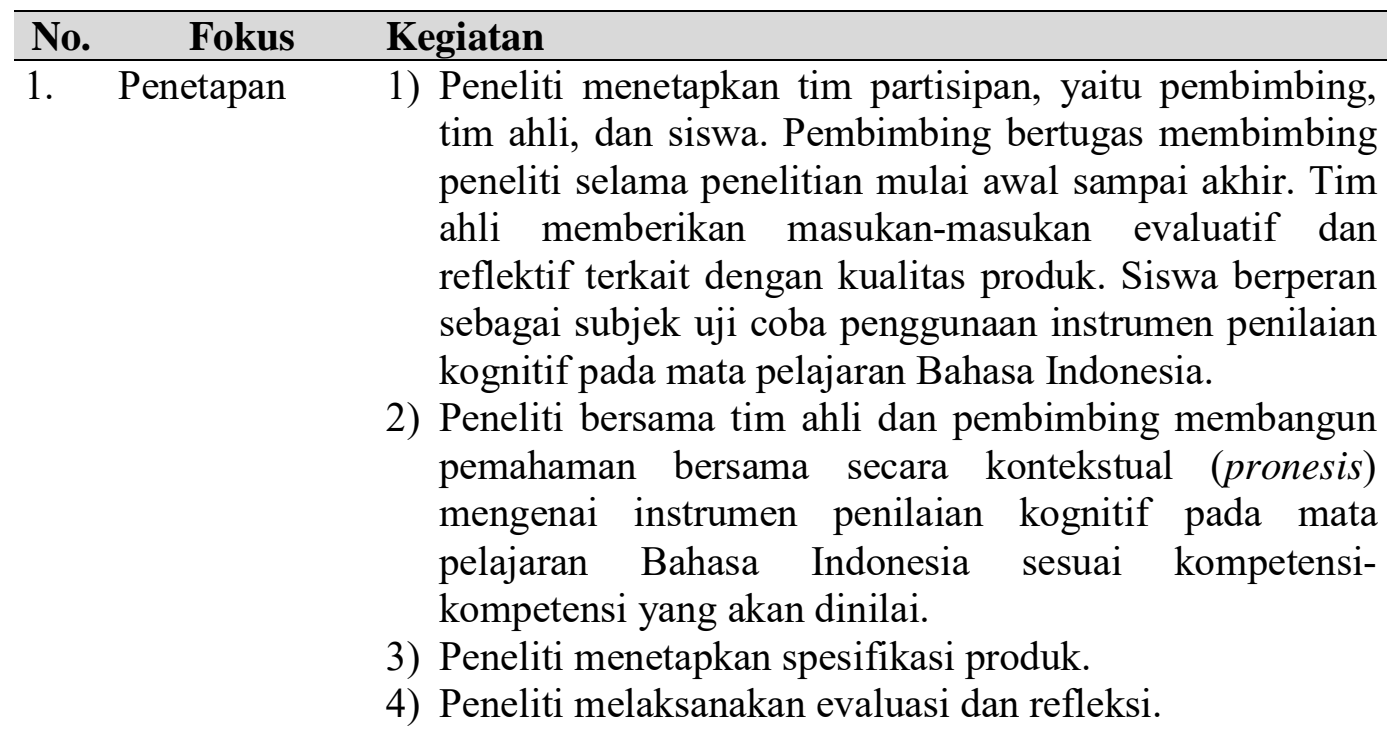

2. Desain dan 1) Menyusun kisi-kisi instrumen penilaian.

pengembangan 2) Mengembangkan soal sesuai kisi-kisi yang telah disusun.

3) Mendesain dan mengembangkan instrumen penilaian standar kompetensi membaca kelas VII berbasis Quipper School.

4) Melaksanakan uji coba (tryout) soal dan analisis butir soal untuk mendapatkan bahan evaluasi dan refleksi.

5) Melaksanakan validasi, evaluasi, dan refleksi.

3. Diseminasi 6) Peneliti mengunggah produk ke internet karena produk ini berupa instrumen penilaian standar kompetensi membaca kelas VII berbasis Quipper School.

7) Peneliti melaksanakan evaluasi dan refleksi.

\section{HASIL DAN PEMBAHASAN}

Produk yang dikembangkan adalah instrumen penilaian untuk standar kompetensi membaca pada mata pelajaran Bahasa Indonesia kelas VII. Produk ini memiliki struktur sebagaimana tampak pada Subbab 4.7, yakni terdiri atas (1) soal semester gasal dan (2) soal semester genap. Soal semester gasal terdiri atas (1) soal KD 3.1 Menemukan makna kata tertentu 
dalam kamus secara cepat dan tepat sesuai dengan konteks yang diinginkan melalui membaca memindai; (2) soal KD 3.2 Menyimpulkan isi bacaan setelah membaca cepat 200 kata per menit; (3) soal KD 7.1 Menceritakan kembali cerita anak yang dibaca; dan (4) soal KD 7.2 Mengomentari buku cerita yang dibaca. Soal semester genap terdiri atas (1) soal KD 11.1 Mengungkapkan hal-hal yg dapat diteladani dari buku biografi yang dibaca secara intensif; (2) soal KD 11.2 Menemukan gagasan utama dalam teks yang dibaca; (3) soal KD 11.3 Menemukan informasi secara cepat dari tabel atau diagram yang dibaca; (4) soal KD 15.1 Membaca indah puisi dengan irama, volume suara, mimik, dan kinesik yang sesuai isi puisi; dan (5) soal KD 15.2 Menemukan realitas kehidupan anak yang terefleksi dalam buku cerita anak baik asli maupun terjemahan.

Produk yang dikembangkan melalui penelitian ini adalah instrumen penilaian standar kompetensi membaca kelas VII berbasis Quipper School. Karena berbasis Quipper School, ada dua aspek yang ditelaah oleh ahli, yaitu (1) struktur dan isi dan (2) bahasa. Data pada masing-masing aspek terbagi menjadi dua macam, meliputi (1) hasil telaah yang berupa penilaian dan (2) hasil telaah yang berupa masukan kritik dan saran.

Pada aspek bahasa, partisipan ahli memberikan skor 5 untuk ejaan, 4 untuk diksi, dan 5 untuk kalimat, sedangkan partisipan praktisi memberikan skor 5 untuk ejaan, diksi, dan kalimat. Pada aspek struktur dan isi, partisipan ahli memberikan skor 5 untuk seluruh soal, sedangkan partisipan praktisi memberikan skor 4 untuk seluruh soal. Total skor dari partisipan ahli adalah 34 dan total skor dari partisipan praktisi adalah 31. Dengan demikian, nilai yang diperoleh adalah 92,85.

Pada perbaikan tahap 1 partisipan ahli memberikan dua kritik terhadap aspek bahasa, yaitu (1) kata-kata yang dimunculkan sebagai bahan bacaan atau soal perlu disesuaikan dengan kultur sekolah dan (2) bahan bacaan sebaiknya bersifat aktual. Pada aspek struktur dan isi, partisipan ahli mempunyai tiga saran, yaitu (1) kesesuaian indikator perlu dicermati lagi, (2) jika teks terlalu panjang dan digunakan untuk sepuluh soal akan kesulitan jika tes berbasis komputer, dan (3) hindari bacaan yang lebih dari satu halaman. Sementara itu, partisipan praktisi menyarankan supaya digunakan teks-teks bacaan yang menonjolkan ciri khas sekolah Muhammadiyah.

Instrumen penilaian kompetensi membaca kelas VII ini meliputi semester gasal dan semester genap. Pada semester gasal terdapat 20 item soal dan pada semester genap terdapat 25 item soal sehingga total keseluruhan soal adalah 45 . Siswa yang berpartisipasi mengerjakan soal berjumlah 42 siswa. Untuk semester gasal, nilai tertinggi adalah 100 dan nilai terendah adalah 53,57. Untuk semester genap, nilai tertinggi adalah 92,67 dan nilai terendah adalah 42,57. Berdasarkan hal itu, sampel kelompok atas dan kelompok bawah masing-masing berjumlah 14 siswa. Lebih jelasnya terlihat pada tabel 2 berikut. 
Tabel 2: Jumlah Benar Siswa Kelompok Atas dan Bawah pada Soal Semester Gasal

\begin{tabular}{|c|c|c|c|c|c|}
\hline \multirow{2}{*}{ Kode KD } & \multirow{2}{*}{ Nomor Soal } & \multicolumn{2}{|c|}{ Siswa Kelompok Atas } & \multicolumn{2}{|c|}{ Siswa Kelompok Bawah } \\
\hline & & Jumlah Benar & $\begin{array}{l}\text { Persentase (\%) } \\
\text { (\%) }\end{array}$ & Jumlah Benar & $\begin{array}{l}\text { Persentase (\%) } \\
\end{array}$ \\
\hline \multirow[t]{2}{*}{3.1} & 1 & 14 & 100 & 7 & 50 \\
\hline & 2 & 14 & 100 & 12 & 86 \\
\hline \multirow[t]{8}{*}{3.2} & 3 & 13 & 93 & 10 & 71 \\
\hline & 4 & 12 & 86 & 10 & 71 \\
\hline & 5 & 14 & 100 & 11 & 79 \\
\hline & 6 & 6 & 43 & 2 & 14 \\
\hline & 7 & 14 & 100 & 7 & 50 \\
\hline & 8 & 9 & 64 & 9 & 64 \\
\hline & 9 & 12 & 86 & 7 & 50 \\
\hline & 10 & 14 & 100 & 11 & 79 \\
\hline \multirow[t]{7}{*}{7.1} & 11 & 14 & 100 & 11 & 79 \\
\hline & 12 & 10 & 71 & 1 & 7 \\
\hline & 13 & 14 & 100 & 11 & 79 \\
\hline & 14 & 14 & 100 & 14 & 100 \\
\hline & 15 & 13 & 93 & 5 & 36 \\
\hline & 16 & 14 & 100 & 3 & 21 \\
\hline & 17 & 14 & 100 & 12 & 86 \\
\hline \multirow[t]{3}{*}{7.2} & 18 & 13 & 93 & 5 & 36 \\
\hline & 19 & 13 & 93 & 11 & 79 \\
\hline & 20 & 14 & 100 & 13 & 93 \\
\hline
\end{tabular}

Siswa kelompok bawah yang berhasil menjawab benar soal nomor 1,7 , dan 9 sejumlah 50\%, yang berhasil menjawab benar soal nomor 2 dan 17 sejumlah $86 \%$, yang berhasil menjawab benar soal nomor 3 dan 4 sejumlah 71\%, dan yang berhasil menjawab benar soal nomor $5,10,11$, 13, dan 19 sejumlah 79\%. Selain itu, untuk soal nomor 15 dan 18, siswa kelompok bawah yang berhasil menjawab benar sejumlah $36 \%$. Untuk soal nomor $12,6,16,8,20$, dan 16, siswa kelompok bawah yang berhasil menjawab benar secara berurutan sejumlah $7 \%, 14 \%, 21 \%$, $64 \%$, 93\%, dan $100 \%$. Jadi, ternyata masih banyak butir soal yang bisa dijawab dengan mudah oleh siswa kelompok bawah, meliputi (1) soal nomor 5, 10, 11, 13 , dan 19 yang mencapai $79 \%$, (2) soal nomor 2 dan 17 yang mencapai $86 \%$, (3) soal nomor 20 yang mencapai $93 \%$, dan (4) soal nomor 16 yang mencapai $100 \%$. Lebih jelas terinci pada tabel 3 berikut.

Tabel 3: Jumlah Benar Siswa Kelompok Atas dan Bawah pada Soal Semester Genap

\begin{tabular}{|c|c|c|c|c|c|}
\hline \multirow{2}{*}{ Kode KD } & \multirow{2}{*}{ Nomor Soal } & \multicolumn{2}{|c|}{ Siswa Kelompok Atas } & \multicolumn{2}{|c|}{ Siswa Kelompok Bawah } \\
\hline & & Jumlah Benar & Persentase (\%) & Jumlah Benar & Persentase $(\%)$ \\
\hline \multirow[t]{4}{*}{11.1} & 1 & 13 & 93 & 11 & 79 \\
\hline & 2 & 5 & 36 & 5 & 36 \\
\hline & 3 & 14 & 100 & 14 & 100 \\
\hline & 4 & 14 & 100 & 14 & 100 \\
\hline \multirow[t]{2}{*}{11.2} & 5 & 8 & 57 & 7 & 50 \\
\hline & 6 & 10 & 71 & 3 & 21 \\
\hline
\end{tabular}




\begin{tabular}{|c|c|c|c|c|c|}
\hline \multirow{5}{*}{ Kode KD } & \multirow{3}{*}{$\begin{array}{c}\text { Nomor Soal } \\
7\end{array}$} & \multicolumn{2}{|c|}{ Siswa Kelompok Atas } & \multicolumn{2}{|c|}{ Siswa Kelompok Bawah } \\
\hline & & Jumlah Benar & Persentase $(\%)$ & Jumlah Benar & Persentase $(\%)$ \\
\hline & & 9 & 64 & 4 & 29 \\
\hline & 8 & 14 & 100 & 9 & 64 \\
\hline & 9 & 10 & 71 & 0 & 0 \\
\hline \multirow[t]{6}{*}{11.3} & 10 & 11 & 79 & 4 & 29 \\
\hline & 11 & 13 & 93 & 11 & 79 \\
\hline & 12 & 10 & 71 & 9 & 64 \\
\hline & 13 & 13 & 93 & 3 & 21 \\
\hline & 14 & 13 & 93 & 4 & 29 \\
\hline & 15 & 0 & 0 & 2 & 14 \\
\hline \multirow[t]{3}{*}{15.1} & 16 & 14 & 100 & 9 & 64 \\
\hline & 17 & 13 & 93 & 6 & 43 \\
\hline & 18 & 10 & 71 & 4 & 29 \\
\hline \multirow[t]{7}{*}{15.2} & 19 & 14 & 100 & 13 & 93 \\
\hline & 20 & 14 & 100 & 13 & 93 \\
\hline & 21 & 14 & 100 & 14 & 100 \\
\hline & 22 & 7 & 50 & 1 & 7 \\
\hline & 23 & 11 & 79 & 7 & 50 \\
\hline & 24 & 12 & 86 & 5 & 36 \\
\hline & 25 & 12 & 86 & 7 & 50 \\
\hline
\end{tabular}

Pada bagian paparan data diketahui bahwa pada butir soal nomor $1,2,5,7$, $10,11,13,14,16,17$, dan 20, jumlah siswa kelompok atas yang berhasil menjawab benar adalah $100 \%$. Pada butir soal nomor 3, 15, 18, dan 19, jumlah siswa kelompok atas yang berhasil menjawab benar adalah 93\%. Pada butir soal nomor 4 dan 9, jumlah siswa kelompok atas yang berhasil menjawab benar adalah $86 \%$. Pada butir soal nomor 12 dan 8 , jumlah siswa kelompok atas yang berhasil menjawab benar adalah $71 \%$ dan $64 \%$, sedangkan pada butir soal nomor 6 , ternyata jumlah siswa kelompok atas yang berhasil menjawab benar hanya $43 \%$.

Berdasarkan hal itu, dilaksanakan analisis butir soal untuk mengetahui tingkat kesukaran soal dan daya pembeda soal. Analisis ini menggunakan indeks maksimal 1,00. Dalam analisis tingkat kesukaran soal, indeks $<0,30$ berarti sukar, indeks 0,31-0,70 berarti sedang, dan indeks 0,71-1,00 berarti mudah. Dalam analisis daya pembeda soal, indeks $<0,19$ berarti buruk sehingga soal harus diperbaiki atau diganti, indeks 0,20-0,29 berarti cukup sehingga soal hanya perlu diperbaiki sedikit, indeks 0,30-0,39 berarti baik sehingga soal sudah layak untuk digunakan namun boleh diperbaiki sedikit, sedangkan indeks $0,40-1,00$ berarti sangat baik sehingga soal sudah sangat layak digunakan dan sama sekali tidak perlu diperbaiki.

Tabel 4: Hasil Analisis Tingkat Kesukaran dan Daya Pembeda pada Soal Semester Gasal

\begin{tabular}{cccccc}
\hline \multirow{2}{*}{ Kode KD } & Nomor Soal & \multicolumn{2}{c}{ Tingkat Kesukaran } & \multicolumn{2}{c}{ Daya Pembeda } \\
\cline { 2 - 5 } & & Indeks & Kategori & Indeks & Kategori \\
\multirow{3}{*}{3.1} & 1 & 0,75 & Mudah & 0,25 & Cukup \\
& 2 & 0,93 & Mudah & 0,07 & Buruk \\
\multirow{3}{*3.2}{} & 3 & 0,82 & Mudah & 0,11 & Buruk \\
& 4 & 0,79 & Mudah & 0,07 & Buruk \\
& & & & & \\
\hline
\end{tabular}

JINoP (Jurnal Inovasi Pembelajaran), Volume 2, Nomor 2, November 2016, hal. 334-350 


\begin{tabular}{lccccc}
\hline Kode KD & Nomor Soal & \multicolumn{2}{c}{ Tingkat Kesukaran } & \multicolumn{2}{c}{ Daya Pembeda } \\
\cline { 2 - 6 } & & Indeks & Kategori & Indeks & Kategori \\
& 5 & 0,89 & Mudah & 0,11 & Buruk \\
& 6 & 0,29 & Sukar & 0,14 & Buruk \\
& 7 & 0,75 & Mudah & 0,25 & Cukup \\
& 8 & 0,64 & Sedang & 0,00 & Buruk \\
& 9 & 0,68 & Sedang & 0,18 & Buruk \\
7.1 & 10 & 0,89 & Mudah & 0,11 & Buruk \\
& 11 & 0,89 & Mudah & 0,11 & Buruk \\
& 12 & 0,39 & Sedang & 0,32 & Baik \\
& 13 & 0,89 & Mudah & 0,11 & Buruk \\
& 14 & 1,00 & Mudah & 0,00 & Buruk \\
& 15 & 0,64 & Sedang & 0,29 & Cukup \\
& 16 & 0,61 & Sedang & 0,39 & Baik \\
& 17 & 0,93 & Mudah & 0,07 & Buruk \\
& 18 & 0,64 & Sedang & 0,29 & Cukup \\
& 19 & 0,86 & Mudah & 0,07 & Buruk \\
& 19 & 0,96 & Mudah & 0,04 & Buruk \\
\hline
\end{tabular}

Sementara itu, hasil analisis daya pembeda soal pada soal semester gasal sebagaimana pada Tabel 4.5 di atas menunjukkan bahwa soal yang berkategori baik hanya 2 butir, yakni soal nomor 12 dan 16. Soal yang berkategori cukup hanya 4 butir, yakni soal nomor 1, 7, 15, dan 18. Adapun, soal yang berkategori buruk masih sangat banyak, mencapai 14 butir, yakni soal nomor 2-6, 8-11, 13, 14, 17,19 , dan 20. Hal itu berarti soal sangat baik masih $0 \%$, soal baik masih hanya $10 \%$, soal cukup hanya $20 \%$, sedangkan soal buruk mencapai 70\%. Dengan demikian, dapat disimpulkan bahwa soal nomor 12 dan 16 sudah bisa digunakan dan tidak akan diperbaiki, soal nomor 1, 7, 15, dan 18 masih bisa digunakan tapi perlu sedikit perbaikan, namun soal nomor $2-6,8-11,13,14,17,19$, dan 20 harus mendapat banyak perbaikan.

Hasil analisis tingkat kesukaran pada soal semester gasal sebagaimana pada tabel berikut menunjukkan bahwa jumlah antara soal yang mudah, sedang, dan sukar masih belum proporsional. Dengan demikian, dapat disimpulkan bahwa instrumen penilaian kompetensi membaca kelas VII semester gasal berbasis Quipper School ini harus diberi perbaikan dalam hal proporsi kesukaran soal.

Tabel 5: Hasil Analisis Tingkat Kesukaran dan Daya Pembeda pada Soal Semester Genap

\begin{tabular}{cccccc}
\hline \multirow{2}{*}{ Kode KD } & Nomor & \multicolumn{2}{c}{ Tingkat Kesukaran } & \multicolumn{2}{c}{ Daya Pembeda } \\
\cline { 2 - 5 } $\mathbf{1 1 . 1}$ & Soal & Indeks & Kategori & Indeks & Kategori \\
& 1 & 0,86 & Mudah & 0,07 & Buruk \\
& 2 & 0,36 & Sedang & 0,00 & Buruk \\
& 3 & 1,00 & Mudah & 0,00 & Buruk \\
\multirow{211.2}{11}{} & 4 & 1,00 & Mudah & 0,00 & Buruk \\
& 5 & 0,54 & Sedang & 0,04 & Buruk \\
& 6 & 0,46 & Sedang & 0,25 & Cukup \\
& 7 & 0,46 & Sedang & 0,18 & Buruk \\
\hline
\end{tabular}




\begin{tabular}{cccccc}
\hline \multirow{2}{*}{ Kode KD } & Nomor & \multicolumn{2}{c}{ Tingkat Kesukaran } & \multicolumn{2}{c}{ Daya Pembeda } \\
\cline { 2 - 6 } & Soal & Indeks & Kategori & Indeks & Kategori \\
& 8 & 0,82 & Mudah & 0,18 & Buruk \\
\cline { 2 - 6 } $\mathbf{1 1 . 3}$ & 9 & 0,36 & Sedang & 0,36 & Baik \\
& 10 & 0,54 & Sedang & 0,25 & Cukup \\
& 11 & 0,86 & Mudah & 0,07 & Buruk \\
& 12 & 0,68 & Sedang & 0,04 & Buruk \\
& 13 & 0,57 & Sedang & 0,36 & Baik \\
& 14 & 0,61 & Sedang & 0,32 & Baik \\
& 15 & 0,07 & Sukar & $-0,07$ & Buruk \\
$\mathbf{1 5 . 1}$ & 16 & 0,82 & Mudah & 0,18 & Buruk \\
& 17 & 0,68 & Sedang & 0,25 & Cukup \\
& 18 & 0,50 & Sedang & 0,21 & Cukup \\
$\mathbf{1 5 . 2}$ & 19 & 0,96 & Mudah & 0,04 & Buruk \\
& 20 & 0,96 & Mudah & 0,04 & Buruk \\
& 21 & 1,00 & Mudah & 0,00 & Buruk \\
& 22 & 0,29 & Sukar & 0,21 & Cukup \\
& 23 & 0,64 & Sedang & 0,14 & Buruk \\
& 24 & 0,61 & Sedang & 0,25 & Cukup \\
& 25 & 0,68 & Sedang & 0,18 & Buruk \\
\hline
\end{tabular}

Struktur dan isi produk menghasilkan soal semester gasal berisi 20 nomor soal objektif dengan rincian adalah (a) soal KD 3.1 berisi dua pertanyaan yang digunakan untuk mengukur kemampuan siswa menentukan makna kata tertentu sesuai konteks; (b) soal KD 3.2 berisi delapan pertanyaan terkait dengan materi isi bacaan, simpulan, gagasan utama, dan kalimat utama yang digunakan untuk mengukur kemampuan siswa menentukan isi bacaan, simpulan yang tepat, gagasan utama, dan kalimat utama, (c) soal KD 7.1 berisi tujuh pertanyaan yang mengukur kemampuan siswa menceritakan kembali cerita anak serta kemampuan siswa menentukan latar, tokoh, dan amanat cerita, dan (d) soal KD 7.2 berisi tiga pertanyaan yang mengukur kemampuan siswa menentukan komentar yang sesuai isi cerita. Sedangkan soal semester genap berisi 25 nomor soal objektif dengan rincian adalah (a) soal KD 11.1 berisi empat pertanyaan yang mengukur kemampuan siswa dalam mengungkapkan hal-hal yang dapat diteladani dari tokoh biografi dan menentukan pelajaran yang bisa diambil dari pengalaman tokoh tersebut. Jadi, ada dua materi pokok dalam KD ini, yaitu hal yang dapat diteladani dan pelajaran berharga, (b) soal KD 11.2 berisi lima pertanyaan yang mengukur kemampuan siswa dalam menentukan gagasan utama dan kalimat utama, (c) soal KD 11.3 berisi enam pertanyaan yang mengukur kemampuan siswa dalam menangkap informasi dari tabel dan diagram, membuat simpulan tentang isi tabel dan diagram, dan membuat pertanyaan yang terjawab oleh isi tabel dan diagram. Oleh sebab itu, ada dua materi pokok dalam KD ini, yaitu tabel dan diagram, (d) soal KD 15.1 berisi tiga nomor soal yang mengukur kemampuan siswa memahami isi puisi, menentukan tema puisi, dan membaca indah puisi, dan (e) soal KD 15.2 berisi enam nomor soal yang mengukur kemampuan siswa menentukan realitas 
kehidupan yang terefleksi dalam cerita, menentukan pelajaran yang bisa diambil dari cerita, menentukan sikap tokoh yang pantas ditiru, dan mengidentifikasi latar cerita.

Pada perbaikan tahap pertama aspek struktur dan isi, partisipan ahli mempunyai tiga saran, yaitu (a) kesesuaian indikator perlu dicermati lagi, (b) jika teks terlalu panjang dan digunakan untuk sepuluh soal akan kesulitan jika tes berbasis komputer, dan (c) hindari bacaan yang lebih dari satu halaman. Sementara itu, partisipan praktisi menyarankan supaya digunakan teks-teks bacaan yang menonjolkan ciri khas sekolah Muhammadiyah. Berdasarkan hal itu, perbaikan yang dilaksanakan ditunjukkan adalah (1) Perbaikan terhadap indikator soal yang kurang sesuai; perbaikan ini dilakukan terhadap indikator KD 3.1 Menemukan makna kata tertentu dalam kamus secara cepat dan tepat sesuai dengan konteks yang diinginkan melalui membaca memindai, KD 7.1 Menceritakan kembali cerita anak yang dibaca, dan KD 11.2 Menemukan gagasan utama dalam teks yang dibaca; (2) Perbaikan terhadap teks bacaan yang terlalu panjang; yang dilakukan dengan memperbaiki teknik penyajian yang terlalu panjang sehingga mempersulit siswa ketika membacanya. Sebagai perbaikannya, peneliti mengubah teknik penyajiannya dengan memberikan side roll sehingga soal tampak lebih praktis dan teks bacaan mudah dibaca; dan (3) Perbaikan terhadap teks bacaan yang temanya kurang aktual dan kurang sesuai kultur Muhammadiyah; hal ini dilakukan pada teks bacaan soal nomor 1 KD 3.1 Menemukan makna kata tertentu dalam kamus sesuai konteks melalui membaca memindai, dan KD 3.2 Menyimpulkan isi bacaan setelah membaca cepat 200 kata per menit, yakni pada soal nomor 1 dan nomor 2 .
Pada aspek bahasa partisipan ahli memberikan dua kritik, yaitu (a) kata-kata yang dimunculkan sebagai bahan bacaan atau soal perlu disesuaikan dengan kultur sekolah, dan (b) bahan bacaan sebaiknya bersifat aktual. Bahasa yang digunakan dalam produk ini adalah bahasa Indonesia dengan ragam bahasa formal yang penulisannya disesuaikan tata aturan EYD (Ejaan Yang Disempurnakan). Penulisan huruf besar diterapkan terhadap setiap awal kalimat serta terhadap setiap awal kata pada setiap nama, seperti nama kota, nama orang, nama instansi, dan lain-lain. Penggunaan cetak miring diterapkan terhadap judul buku dan kata yang berbahasa asing. Tanda titik diberikan pada setiap akhir kalimat. Tanda koma diberikan pada setiap anak kalimat yang mendahulu induk kalimat pada kalimat majemuk bertingkat. Tanda koma juga digunakan untuk memisahkan penyebutan rincian dalam satu kalimat.

Selain memperhatikan ejaan, penggunaan bahasa formal dalam produk ini juga memperhatikan efektivitas kalimat. Oleh sebab itu, ada beberapa bentuk kalimat yang dihindari dalam produk. Pertama, kalimat tidak utuh adalah kalimat yang tidak memiliki fungsi minimal, yaitu fungsi subjek dan predikat. Contoh, kalimat 'Seluruh siswa yang akan mengikuti upacara peringatan kemerdekaan RI di Stadion Brantas Kota Batu dengan memakai seragam HW' adalah kalimat yang tidak utuh. Setiap kalimat harus memiliki minimal subjek dan predikat. Kedua, kalimat ambigu adalah kalimat yang memiliki dua maksud atau lebih. Contoh, kalimat 'Menurut pemeriksaan dokter Arif Budiman terkena DBD' adalah kalimat ambigu karena mengandung maksud yang lebih dari satu sehingga membingungkan pembaca. Kalimat tersebut bisa berarti 
Budiman terkena DBD menurut hasil pemeriksaan dokter Arif, bisa pula berarti Arif Budiman terkena DBD berdasarkan hasil pemeriksaan dokter. Kalimat tersebut seharusnya diberi tanda koma, misalnya Menurut pemeriksaan dokter, Arif Budiman terkena DBD. Ketiga, kalimat tidak logis adalah kalimat yang maknanya tidak sesuai dengan logika atau nalar manusia. Contoh, kalimat 'Naik sepeda harap turun' adalah kalimat yang tidak logis karena naik sepeda adalah perbuatan, bukan orang, sehingga tidak mungkin bisa disuruh turun. Seharusnya, kalimat tersebut diubah menjadi 'Pengendara sepeda diharap turun'. Keempat, kalimat tidak lugas adalah kalimat yang tidak efisien, berlebihan dalam penggunaan kata padahal bisa dengan kata-kata yang lebih sederhana atau lebih sedikit. Contoh, kalimat 'Mereka membicarakan tentang program sekolah' dan kalimat Polisi dan teroris saling tembak-menembak adalah kalimat yang tidak lugas karena penggunaan kata yang berlebihan. Pada contoh kalimat pertama seharusnya tidak menggunakan kata tentang, sedangkan pada contoh kalimat kedua seharusnya tidak menggunakan kata saling. Kelima, kalimat berstruktur bahasa lain adalah kalimat yang menggunakan struktur bahasa daerah atau bahasa asing. Contoh, kalimat 'Ibunya Didik tadi pagi meninggal dunia' adalah kalimat yang strukturnya dipengaruhi bahasa daerah, sedangkan kalimat 'Rumah di mana saya tinggal sedang diperbaiki' adalah kalimat yang strukturnya dipengaruhi bahasa asing. Contoh kalimat pertama seharusnya tidak menggunakan imbuhan nya, sedangkan contoh kalimat kedua seharusnya tidak menggunakan kata di mana sehingga kalimatnya diubah menjadi Rumah yang saya tempati sedang diperbaiki.

\section{Kajian Keunggulan dan Kelemahan Produk}

Produk berupa instrumen penilaian standar kompetensi membaca untuk siswa kelas VII berbasis Quipper School ini memiliki beberapa keunggulan yang ditinjau dari tiga aspek, yaitu (1) kualitas soal, (2) keperluan, dan (3) penggunaan. Dari segi kualitas soal, produk ini memiliki empat keunggulan. Pertama, sudah melalui uji coba dan analisis butir soal sehingga tingkat kesukaran soal dan daya pembeda soal sudah teruji dan sudah diperbaiki. Kedua, produk ini sudah melalui proses uji telaah ahli dan telah diperbaiki berdasarkan masukan-masukan dari ahli, baik dari segi isi bacaan, bahasa yang digunakan, kisi-kisinya, dan lain-lain. Ketiga, dalam Taksonomi Bloom, produk ini tidak hanya mengukur ranah pengetahuan (C1) dan pemahaman (C2), namun juga mengukur kemampuan penerapan (C3), analisis (C4), sintesis (C5), dan evaluasi (C6) yang dimiliki siswa. Keempat, produk ini memiliki akurasi pengukuran dan penilaian yang objektif sehingga terhindar dari subjektivitas guru.

Dari segi keperluan, produk ini juga memiliki empat keunggulan. Pertama, produk ini bisa digunakan untuk mendiagnosis kemampuan siswa secara detail pada tiap-tiap kompetensi dasar. Dengan produk ini Quipper akan menganalisis persentase penguasaan siswa pada tiap-tiap kompetensi dasar yang diujikan oleh guru. Guru pun bisa langsung mengakses persentase penguasaan siswa pada tiap-tiap kompetensi dasar itu sekaligus mengunduhnya. Guru bisa membuat pemetaan tentang siswa-siswa yang kurang menguasai dan yang sudah menguasai $\mathrm{KD}$ atau materi tertentu. Dengan demikian, langkah tindak lanjut yang berupa pelajaran tambahan persiapan 
ujian nasional bisa dilaksanakan secara lebih akurat sesuai hasil pemetaan tersebut. Kedua, produk ini bisa digunakan untuk memberikan ulangan blok. Untuk keperluan ini, ulangan harus dilaksanakan secara serentak pada waktu dan tempat yang sama agar guru bisa melakukan pengawasan dan siswa tidak melakukan kecurangan. Ketiga, produk ini bisa digunakan untuk memberikan tugas atau pekerjaan rumah (PR) pada siswa dan mewajibkan siswa mengerjakannya pada jam yang telah ditentukan dan diatur oleh guru. Keempat, produk ini bisa digunakan untuk memberikan latihan persiapan ujian nasional pada siswa. Dari segi penggunaan, produk ini memiliki beberapa keunggulan. Pertama, produk ini bisa diakses menggunakan ponsel, tablet, laptop, dan komputer sehingga siswa bisa mengerjakan soal-soal dari rumah dengan salah satu alat yang mereka miliki. Kebanyakan siswa sekarang sudah memiliki ponsel atau tablet sehingga kehadiran produk ini akan dapat mengarahkan siswa pada penggunaan ponsel secara positif, tidak sekadar untuk sosial media dan bermain game. Kedua, produk ini bisa diakses dari mana saja dan kapan saja asalkan ada koneksi internet. Di kota Batu mulai dari kota pusat sampai pinggiran sudah ada internet, bahkan ponsel yang rata-rata dimiliki anak-anak pun sudah bisa tersambung ke internet. Ketiga, tampilan menu dan fitur dalam produk ini mudah dipahami oleh siswa sehingga ketika akan mengerjakan soal, siswa tidak kebingungan.

Produk berupa instrumen penilaian standar kompetensi membaca untuk siswa kelas VII berbasis Quipper School ini memiliki empat kelemahan. Kelemahan yang pertama adalah dari segi jenis soal, sedangkan kelemahan yang kedua, ketiga, dan keempat adalah dari segi penggunaannya. Kelemahan pertama, teknik penilaian yang digunakan dalam produk ini hanya berupa teknik tes objektif, padahal tidak semua kompetensi bisa dinilai hanya dengan tes objektif. Untuk mengukur kompetensi yang dikuasai oleh siswa secara utuh diperlukan tes praktik juga. Kelemahan kedua, ada kemungkinan siswa membuka buku atau bertanya pada teman saat mengerjakan soal. Kelemahan ketiga, guru tidak bisa melakukan pengawasan terhadap cara siswa mengerjakan soal, bisa jadi siswa membuka buku, bertanyatanya kepada teman atau orang lain. Kelemahan keempat, apabila terjadi slow connection pada jaringan internet, maka kemungkinan nilai tidak akan masuk ke sistem sehingga siswa harus mulai mengerjakan lagi dari awal.

\section{Antisipasi Kelemahan Produk}

Sesuai dengan jumlah kelemahan produk, langkah antisipasi kelemahan produk ini juga terbagi menjadi empat langkah. Pertama, hendaknya guru tidak menjadikan produk ini sebagai satu-satunya instrumen penilaian sehingga selain instrumen ini guru masih perlu mempersiapkan instrumen lain untuk mengukur kompetensi siswa secara karena beberapa kompetensi memerlukan tes praktik. Kedua, menggunakan instrumen ini untuk memberikan tugas rumah atau PR sehingga siswa diperbolehkan membuka buku atau bertanya kepada teman. Ketiga, jika instrumen penilaian ini digunakan untuk ulangan maka sebaiknya ulangan dilaksanakan serentak di tempat dan waktu yang sama dalam pengawasan guru, besar kemungkinan dilaksanakan di laboratorium komputer atau di ruang kelas dengan menggunakan ponsel, tablet, atau laptop. Hal ini paling tidak dapat memberikan pengalaman baru tentang ulangan pada siswa, sedangkan bagi guru hal ini merupakan efisiensi dalam koreksi 
dan analisis karena koreksi dan analisis telah dikerjakan secara otomatis oleh Quipper School. Keempat, sebelum menggunakan produk ini sebaiknya guru atau siswa memeriksa kualitas koneksi internet pada saat itu. Semua ponsel, tablet, atau laptop biasanya secara otomatis menunjukkan kuat tidaknya sinyal. Kelima, dibanding di daerah perkotaan penggunaan Quipper School di pedesaan belum dapat diterapkan karena terbatasnya koneksi dan jaringan internet.

\section{SIMPULAN}

Penelitian pengembangan ini menghasilkan sebuah produk yang berupa instrumen penilaian standar kompetensi membaca untuk siswa kelas VII berbasis Quipper School. Produk ini memang dikhususkan bagi siswa SMP/MTs. Semua produk tentu memiliki keunggulan dan kelemahan, begitu pula dengan produk hasil penelitian dan pengembangan ini. Meski demikian, bukan berarti produk ini tidak bisa digunakan. Berikut ini dipaparkan deskripsi produk, kajian keunggulan dan kelemahan produk, antisipasi produk, dan saran-saran.

Pembahasan terhadap produk hasil pengembangan ini difokuskan pada tiga aspek, yaitu struktur, isi, dan bahasa.

Produk yang dikembangkan adalah instrumen penilaian untuk standar kompetensi membaca pada mata pelajaran Bahasa Indonesia kelas VII. Produk ini memiliki struktur, yakni terdiri atas (1) soal semester gasal dan (2) soal semester genap. Soal semester gasal terdiri atas (1) soal KD 3.1 Menemukan makna kata tertentu dalam kamus secara cepat dan tepat sesuai dengan konteks yang diinginkan melalui membaca memindai; (2) soal KD 3.2 Menyimpulkan isi bacaan setelah membaca cepat 200 kata per menit; (3) soal KD 7.1 Menceritakan kembali cerita anak yang dibaca; dan (4) soal KD 7.2 Mengomentari buku cerita yang dibaca. Soal semester genap terdiri atas (1) soal KD 11.1 Mengungkapkan hal-hal yg dapat diteladani dari buku biografi yang dibaca secara intensif; (2) soal KD 11.2 Menemukan gagasan utama dalam teks yang dibaca; (3) soal KD 11.3 Menemukan informasi secara cepat dari tabel atau diagram yang dibaca; (4) soal KD 15.1 Membaca indah puisi dengan irama, volume suara, mimik, dan kinesik yang sesuai isi puisi; dan (5) soal KD 15.2 Menemukan realitas kehidupan anak yang terefleksi dalam buku cerita anak baik asli maupun terjemahan.

Bahasa yang digunakan dalam produk ini adalah bahasa Indonesia dengan ragam bahasa formal yang penulisannya disesuaikan tata aturan EYD (Ejaan Yang Disempurnakan). Penulisan huruf besar diterapkan terhadap setiap awal kalimat serta terhadap setiap awal kata pada setiap nama, seperti nama kota, nama orang, nama instansi, dan lain-lain. Penggunaan cetak miring diterapkan terhadap judul buku dan kata yang berbahasa asing. Tanda titik diberikan pada setiap akhir kalimat. Tanda koma diberikan pada setiap anak kalimat yang mendahulu induk kalimat pada kalimat majemuk bertingkat. Tanda koma juga digunakan untuk memisahkan penyebutan rincian dalam satu kalimat. Selain memperhatikan ejaan, penggunaan bahasa formal dalam produk ini juga memperhatikan efektivitas kalimat. Oleh sebab itu, ada beberapa bentuk kalimat yang dihindari dalam produk ini, seperti: (a) kalimat tidak utuh adalah kalimat yang tidak memiliki fungsi minimal, yaitu fungsi subjek dan predikat. Setiap kalimat harus memiliki minimal subjek dan predikat; (b) kalimat ambigu adalah kalimat yang memiliki dua maksud atau lebih; (c) kalimat tidak logis adalah kalimat yang maknanya 
tidak sesuai dengan logika atau nalar manusia; dan (d) kalimat tidak lugas adalah kalimat yang tidak efisien, berlebihan dalam penggunaan kata padahal bisa dengan katakata yang lebih sederhana atau lebih sedikit.

Kalimat berstruktur bahasa lain adalah kalimat yang menggunakan struktur bahasa daerah atau bahasa asing. Produk berupa instrumen penilaian standar kompetensi membaca untuk siswa kelas VII berbasis Quipper School ini memiliki beberapa keunggulan yang ditinjau dari tiga aspek, yaitu (1) kualitas soal, (2) keperluan, dan (3) penggunaan.

Produk berupa instrumen penilaian standar kompetensi membaca untuk siswa kelas VII berbasis Quipper School ini memiliki empat kelemahan. Kelemahan yang pertama adalah dari segi jenis soal, sedangkan kelemahan yang kedua, ketiga, dan keempat adalah dari segi penggunaannya. Sesuai dengan jumlah kelemahan produk, langkah antisipasi kelemahan produk ini juga terbagi menjadi empat langkah. Pertama, hendaknya guru tidak menjadikan produk ini sebagai satusatunya instrumen penilaian sehingga selain instrumen ini guru masih perlu mempersiapkan instrumen lain untuk mengukur kompetensi siswa secara karena beberapa kompetensi memerlukan tes praktik. Kedua, menggunakan instrumen ini untuk memberikan tugas rumah atau PR sehingga siswa diperbolehkan membuka buku atau bertanya kepada teman. Ketiga, jika instrumen penilaian ini digunakan untuk ulangan maka sebaiknya ulangan dilaksanakan serentak di tempat dan waktu yang sama dalam pengawasan guru, besar kemungkinan dilaksanakan di laboratorium komputer atau di ruang kelas dengan menggunakan ponsel, tablet, atau laptop. Hal ini paling tidak dapat memberikan pengalaman baru tentang ulangan pada siswa, sedangkan bagi guru hal ini merupakan efisiensi dalam koreksi dan analisis karena koreksi dan analisis telah dikerjakan secara otomatis oleh Quipper School. Keempat, sebelum menggunakan produk ini sebaiknya guru atau siswa memeriksa kualitas koneksi internet pada saat itu. Semua ponsel, tablet, atau laptop biasanya secara otomatis menunjukkan kuat tidaknya sinyal.

Berdasarkan kajian di atas, maka dapat dikemukakan saran yang ditujukan kepada beberapa pihak, sebagai berikut. Pertama, kepada para kepala sekolah/ madrasah, disarankan supaya mengadakan proyek pengembangan instrumen penilaian berbasis Quipper School melalui pengadaan workshop atau semacamnya untuk seluruh mata pelajaran di sekolahnya masing-masing. Kedua, kepada para guru disarankan agar ikut mengembangkan instrumen penilaian dengan menggunakan Quipper School, bahkan akan lebih baik mengembangan bahan ajar dan materi menggunakan Quipper School. Ketiga, peneliti sangat berharap kepada pihakpihak yang memiliki kompetensi dan kemampuan, baik dalam hal teknis maupun pendanaan, supaya turut berpartisipasi dalam pengembangan lanjutan yang lebih relevan dan lebih berguna.

\section{DAFTAR PUSTAKA}

Arifin, Zainal. Evaluasi Pembelajaran. Bandung: Remaja Rosdakarya. Cetakan Ke- 5. 2013.

Haryati, Mimin. 2009. Model dan Teknik Penilaian pada Tingkat Satuan Pendidikan. Jakarta: Gaung Persada Press.

Khoiri, Nur. 2014. "Pengembangan Perangkat Penilaian Pembelajaran Menulis Karya Ilmiah (Bahasa Indonesia) untuk Siswa SMP”. NOSI, volume 2 (1): 37-52. 
Nurgiyantoro, Burhan. 2008. "Penilaian Otentik". Cakrawala Pendidikan, volume 27 (3): 250-261.

Peraturan Menteri Pendidikan Nasional Republik Indonesia Nomor 20 Tahun 2007 tentang Standar Penilaian Pendidikan. Jakarta: Menteri Pendidikan Nasional Republik Indonesia. (Online), (http://rethno23. blogspot.co.id/2012/04/standarpenilaian-dan-permendiknas-no.html), diakses 2 Januari 2015.

Peraturan Menteri Pendidikan Nasional Republik Indonesia Nomor 22 Tahun 2006 tentang Standar Isi. Jakarta: Menteri Pendidikan Nasional Republik Indonesia. (Online), (http:// bsnp-indonesia.org), diakses 25 September 2015.

Rahayu, Tuti. 2008. "Pengembangan Instrumen Penilaian dalam Pendidikan Matematika Realistik Indonesia (PMRI) di SMPN 17 Palembang”. Jurnal Pendidikan Matematika, volume 2 (2): 19-35.

Sahab, Marwan Mizher. 2012. The Effect of Text Type on The EFL learner's Comprehension. Tikrit University Journal for Humanities, (Online), Vol. 19 (2): 31-55, (http:// www.iasj.net), diakses 24 Juli 2014.

Sugiyono. 2013. Metode Penelitian Pendidikan: Pendekatan Kuantitatif, Kualitatif, dan R\&D. Bandung: Penerbit Alfabeta.

Sujadi. 2003. Metodologi Penelitian Pendidikan. Jakarta: Rineka Cipta.

Tarigan, Henry Guntur. 2012. Membaca sebagai Suatu Keterampilan Berbahasa. Bandung: Penerbit Angkasa.

Undang-Undang Republik Indonesia Nomor 20 Tahun 2003 tentang Sistem Pendidikan Nasional. Jakarta: Presiden Republik Indonesia.
Wahyuni, Sri \& Ibrahim, Abdul Syukur. 2012. Asesmen Pembelajaran Bahasa. Bandung: Refika Aditama.

Willis, Jerry W. 2009. Constructivist Instructional Design (C-ID): Foundations, Models, and Examples. Charlotte: Information Age Publishing. 